\title{
Social movement unionism and social partnership in Germany: the case of Hamburg's hospitals
}

\author{
Ian Greer \\ Published in Industrial Relations, Vol. 47, Issue 4, pp. 602-624, October $2008^{\mathrm{i}}$
}

\begin{abstract}
This paper traces the emergence of social movement unionism in Hamburg, Germany, as labor's channels of influence have broken down and economic pressures have intensified. Trade unionists have responded to the privatization of the municipal hospitals by mobilizing members and building coalitions around issues beyond their members' immediate interests, including democracy and public service quality. Although the loss of union influence has facilitated social movement unionism, in East Germany economic crisis has had a demobilizing effect.
\end{abstract}

\footnotetext{
${ }^{\mathrm{i}}$ First and foremost, thanks to the interviewees. For helpful comments and corrections, thanks to Virginia Doellgast, Marco Hauptmeier, Klaus-Dieter Schwettscher, Nils Böhlke, Lowell Turner, Thorsten Schulten, three anonymous referees, editor Dan Mitchell, the participants of the track, "Organizing Migrants and Social Movements," at the EGOS Colloquium of 6-8 July 2006 in Bergen and the participants in the seminar at WSI on 6 March 2007 in Düsseldorf. The research was supported by the German Academic Exchange Service, the Max Planck Institute for the Study of Societies, and the Hans Böckler Foundation.
} 
In Germany, like many countries, unions have traditionally had two institutionalized ways to ratchet up labor standards: the industrial relations system and the political system. Both kinds of influence, however, have become less effective, as employers have created low-paying precarious jobs and state and local governments have excluded unionists from the policymaking process. Most policymakers have come to view the intensification of competition, the search for competitiveness, and the elimination of barriers to competition, including worker protections, as the keys to general well-being. Unions have had difficulty adapting.

For industrial relations theorists, this has come as a surprise. While comparative industrial relations scholars have long discussed Germany within the context of globalization, they have treated it as a "coordinated market economy." Global market pressures, in this scheme, are mediated by an institutional framework that produced both a rising standard of living for blue-collar workers and economic competitiveness. Trade unions played a crucial role establishing these institutions, extending them to East Germany, and reforming them in line with economic and political pressures. This connection to the political and industrial relations systems became central to trade union strategies and identities.

Recently, the institutional embeddedness of German unions has been undermined in two ways. First, in some places, in-firm cooperation has intensified, hardening the segments of the labor market, and leading to concession bargaining. This tends to undermine uniform wage and work times in industry, a central feature of employer-side coordination (Doellgast and Greer 2007; Thelen and Kume 2006), and within large corporations it creates conflicts between worker-side "co-managers" and their opponents (Rehder 2006). Second, elsewhere, conflict 
between labor and management has intensified, as unions have responded to employer moves to avoid workplace-level worker representation (as at the supermarket chain Lidl - see http://www.verdi-blog.de/lidl) or fragment collective bargaining (as in the public sector Bispinck 2006). Much has been written on the first trend, less on the second.

This paper examines the case of Hamburg's municipal hospitals, where unions have tried both cooperation and contention in response to intensified competition. Although trade unionists accept the need for private capital and reduced costs, their channels of influence have largely disappeared. As a result, they have turned away from social partnership and mobilized workers and citizens of Hamburg around protecting public services and jobs, shifting to a strategy that resembles what scholars have begun to call social movement unionism.

At issue is a change in how worker representatives have participated in hospital restructuring since the mid 1990s. For Hamburg's patients and workers, the stakes have been high: Landesbetrieb Krankenhäuser (LBK) was the city's second largest employer, after Airbus, and controlled half of the city's hospital beds. The story begins in 1995 when the government announced a program to rationalize the hospitals, including the formation of LBK. It ends in 2007 with a collective agreement over the terms of a handover of LBK to a private firm, Asklepios, and, not incidentally, the revitalization of the union. Between these two events is a turning point, the 2001 defeat of the Social Democrats in local elections, which undermined the union's channels of influence over workplace restructuring.

In Germany, as ruling political parties and employers lose their interest in social partnership, union strategies are changing. German unions, like their colleagues elsewhere, are not just embedded in industrial relations institutions, but also in other social relations, such as local politics and civil society. These additional channels of influence and power resources can be attractive to unions seeking alternatives to the eroding industrial relations system. Looking at 
change over time in Hamburg, I argue that, as channels of union influence in the state and employer weaken, the extent to which unions counter restructuring with mobilization and coalition building tends to increase. From a comparison of four other regions, I show that mobilization can be hampered by (1) strong channels of union influence in local government and (2) local economic crisis.

This paper is based on 43 interviews with 29 trade union staff, rank-and-file activists, works councilors, politicians, community activists and administrators between 2003 and 2007 . Interviews were semi-structured: while they covered a shared set of issues, questions changed along with events and as specific categories emerged as important. While the most detailed research took place Hamburg, interviews were also conducted in Berlin (the site of the national union office), Stuttgart, Chemnitz and Cologne. Hamburg's hospitals were chosen as the main case, for a few reasons. The former LBK is massive (15,000 employees in 1995, 11,000 in 2007) and an important employer and provider of public services. Despite their importance, hospitals are under-researched: what we know about German industrial relations is based primarily on large manufacturing firms. For a researcher, it helps that the press, academics, consultants and managers have documented the restructuring there and made their writings publicly available, and that the individuals on nearly all sides of the dispute ${ }^{\mathrm{i}}$ agreed to be interviewed for this study. Most importantly, the case did not fit the usual image of German trade unionism and therefore seemed productive in showing the limits of mainstream theory. The other cities were chosen to reflect diversity within Germany: the conservative and affluent southwest (Stuttgart), the social democratic Rhineland (Cologne) and the crisis-ridden east (Berlin and Chemnitz).

This paper begins with a discussion of why industrial relations theorists view social movement unionism as unlikely in Germany. The following section describes the rise of labormanagement-government cooperation in Hamburg, the changes in industrial relations, the health 
care system and local politics that disrupted these old arrangements, and the emergence of social movement unionism after 2001. Next is a comparison of hospital restructuring and industrial relations in four other large cities in order to assess generalizability. Finally, it assesses international comparative explanations of trade unionism in light of the argument and cases, especially the U.S.-German contrast that has so deeply influenced institutional theory.

\section{Industrial relations theory and the likelihood of social movement unionism in Germany}

Scholars generally view it as unlikely the German unions would behave like social movements. The term, social movement unionism, has been used as a vision of international solidarity (e.g. Moody 1997) and to describe more local forms of mobilization, mainly in the U.S. (e.g. Johnston 1994). Steven Lopez defines social movement unionism within the latter tradition, as a type of trade union that develops genuine community coalitions, grassroots worker mobilization and recruitment outside the usual tool of the strike, and frames issues in terms of social justice rather than the interests of the workers involved (2004: 12-13). It is this kind of innovation, others have argued, that is stifled by the institutional embeddedness of German unions (Baccaro, Hamann and Turner 2003; Frege and Kelly 2004).

German unions, according to this line of reasoning, have relatively unchallenged roles in the national political economy. Since the 1980s, Germany's "neo-corporatist" institutions have attracted the admiration of writers in countries with "pluralist" systems. ${ }^{\text {ii }}$ While Britain suffered from a vicious cycle of distrust, contention and industrial decline, Germany had a virtuous cycle of high wages, high skills, labor peace and economic expansion. While American unions were vulnerable to the vicissitudes of management strategy, with little choice but to act as management's junior partner, German unions participated with strong statutory rights and mobilization capacities. The kind of management offensive led by Reagan and Thatcher never 
Page 5

took place in Germany, partly because managers in the large firms that dominated employer associations feared conflict (see Streeck 1992; Turner 1991; Thelen and Kume 2006).

The advantages that West German industrial relations system conferred on the postwar trade unions can hardly be exaggerated. Collective bargaining agreements covered more than $80 \%$ of employees and were very inclusive. For example, the metal and electronics industry agreement negotiated by the union IG Metall covered manufacturers of motor vehicles, auto parts, ships, airplanes, computers, machine tools, and the metals and metal components used to manufacture all of the above. Germany's employers had few exit options, since (1) the employers associations that conducted collective bargaining also provided services to employers such as legal support in the case of a dispute in the workplace and (2) under German law, all members of the associations were bound by the collective agreements they negotiated. Furthermore, employers did not necessarily want to escape, since negotiating wages at the sectoral level, rather than in the workplace, displaced conflict. Works councils, the in-firm worker representatives, had participation rights of their own, a formal separation from the union, and were not allowed to call strikes. Most works councilors, however, were union members, and many were union activists and recruited members. Although mandatory union membership was illegal, these arrangements helped keep union density above one third of the workforce for most of the postwar period.

Institutional embeddedness, however, had a downside for unions, which became evident as they came under attack. A small number of unified unions (Einheitsgewerkschaften) operated with little competition, with less pressure to compete for members than in pluralist systems of interest representation, such as the U.K. (Hassel 1999). As non-union employer associations came into being and as high unemployment made workers less willing to strike, unions were increasingly marginalized in their shrinking strongholds of large manufacturing firms. Unions 
were accused of becoming the representatives of an ever more narrowly defined interest group and of shifting the cost of economic restructuring onto society as a whole through statesubsidized early retirement schemes (Streeck 2001). In-firm labor-management cooperation tended to subvert the system by intensifying inequality in the labor market, political conflict within the camp of worker representatives (Rehder 2006), and competition between different parts of the workforce (Doellgast and Greer 2007). At the same time, because unions had faced relatively little "challenge to [their] legitimate status" and had a "framework of employment law [that] has remained broadly supportive," they were under little pressure to build coalitions with other organizations in civil society (Frege, Heery and Turner 2004: 146).

These problems with institutional embeddedness were discovered during a period of union decline. At the end of 2006, the German unions' umbrella organization, the Deutscher Gewerkschaftsbund (DGB), reported the combined membership of its affiliate unions at 6.6 million members, down from 7.8 million in 2000 and 11 million in 1992 (personal communication with the DGB). Density estimates are difficult to make, due to the poor quality of the data, but the best estimate put it at 20\% in 2005 (Ebbinghaus 2005, p. 22). Union bargaining power has declined, as well. Not only has the percentage of employers free of bargaining increased, but after the 2003 strike in East Germany, unions experienced a string of defeats in their strongholds, including the automakers, Siemens, Deutsche Telekom and the public sector. Union political power also seems to have declined. The ongoing fragmentation of public sector collective bargaining (discussed below) and the welfare-to-work laws of 2003 were only two examples of government actions that unions opposed and that undermined union power.

The fortunes of German unions have thus changed dramatically, for the worse, along with changes in the national political economy. The decline of unions' bargaining and political power has amounted to an erosion of the unions' institutional embeddedness, reinforced by membership 
decline. As the advantages of the German model to trade unionism fade, can we still say that the institutions constrain innovation, that neo-corporatist action follows neo-corporatist structure? Below, I will argue that because of these changes, institutional theories of union behavior are losing their explanatory power.

\section{Trade unionism and the restructuring of Hamburg's hospitals}

\section{Pre-2001: Restructuring under social partnership}

In the post-World War II era, the Social Democratic Party (SPD) led Hamburg's local government continuously for 44 years, at times in coalition with the Liberal Democrats or the Greens. Since the SPD had close ties with union leaders, unions received access to government policymaking in the executive branch (a 9-member Senate, led by an Erster Bürgermeister) and the legislative branch (the 120-member Bürgerschaft). As in other regions, public sector managers tended to be members of political parties, including the SPD, giving trade unions channels of influence above the minimum statutory requirement.

In some ways, the state-owned part of the health care system fits the standard picture of German industrial relations. Centralized trade unions, employers associations and collective bargaining cover the whole public sector, and tripartite bodies govern hospital financing. LBK workers are represented by ver.di, a conglomerate union of service sector workers that formed in 2001 from a merger of five unions. Prior to the merger, two of these unions had a substantial membership in health care, Öffentliche Dienste, Transport und Verkehr (ÖTV) and the Deutsche Angestelleten Gewerkschaft (DAG), and a professional organization, the Marburger Bund, represented physicians. Although the DAG and the Marburger Bund were independent of the DGB, they coordinated bargaining with ÖTV as co-signatories to the same agreements, and in 2001 DAG and ÖTV merged with three other unions into the vereinte 
Page 8

Dienstleistungsgewerkschaft, or ver.di. Collective bargaining in German hospitals followed the guidelines of a nation-wide public sector bargaining framework. Before a round of reforms in 2005, it was called the Bundesangestelltentarifvertrag (BAT); the new agreement, the Tarifvertrag für den öffentlichen Dienst (TVöD), covers nearly 3 million workers. State, local and federal governments are represented by three employers associations, and, like the pre-ver.di unions, are parties to the same agreement. Although the extent of co-determination varies according to the state and the enabling laws setting up specific government-owned corporations, the public sector, like the private sector, does have works councilors and - depending on the legal form of their agency - worker seats on supervisory boards.

In the mid-1990s, Hamburg's municipal hospitals were targeted for modernization. City councilors argued that the hospitals were not efficient enough to cope with pressures from the conservative federal government and the cash-strapped local health insurance funds. Government and management announced a cost reduction goal of DM 200 million, along with plans to close a historic hospital, the Hafenkrankenhaus. The latter move sparked an occupation of the building by union and community activists, which culminated in a negotiated solution.

The deal was worked out by unionists, works councils, managers and politicians, mostly affiliated with the SPD, with the goal of finding efficiencies and preventing mandatory redundancies. A new works council had just been elected to replace a more militant group, and they viewed "trusting cooperation" (vertrauensvolle Zusammenarbeit) as more productive than confrontation. LBK's personnel director, Heinz Lohmann, an SPD member, was in charge of negotiating with worker representatives over the effects of restructuring. SPD politicians including the head of the DGB, Erhard Pumm, who sat on the city council - wrote and passed the enabling legislation for the new LBK. This common affiliation, and this common belief in using collective bargaining and legislation to modernize the hospitals, led to a typical, German-style 
compromise for "socially tolerable" cost cutting. A complex set of rules emerged to regulate work in the new organization, including a "cooperation contract" specifying a structure of committees and information rights to steer change. The government passed a law specifying LBK's organizational structure and securing, among other things, priority hiring elsewhere in Hamburg's public sector for workers leaving LBK.

Documentation of these changes by managers (Schütte 2004) and worker representatives (Brueckner-Bozetti and Schweizer 2000) show that these agreements allowed LBK managers to reduce costs in several ways. The union agreed to accept the closure of the Hafenkrankenhaus and headcount reductions of 3000 out of 15,000 workers in exchange for a "right of return" (i.e. privileged access to work elsewhere in Hamburg's public sector) and detailed consultations over restructuring. With the support of outside consultants, the works council hoped to reduce the cuts and prevent mandatory redundancies.

Management's goal was to reduce costs by $15 \%$. In consultation with the union, they reorganized support services into separate subsidiaries, some as joint ventures with outside firms. LBK set up 100\%-owned subsidiaries in charge of cleaning, pharmacy and laundry, as well as several "service firms" in which functions like buying, logistics, facilities management and training were concentrated on a single site within the organizational structure. While most these areas remained within the sectoral agreement, the combining of redundant capacities across the hospitals allowed management to reduce employment numbers. Eventually, they reached their goal of 3000 fewer employees, mainly through attrition.

\section{National trends in hospital industrial relations}

Much of what eventually happened in Hamburg - the downsizing, restructuring and privatization, and the demands to deviate from national-sectoral collective bargaining - was not 
Page 10

unusual. Between 1991 and 2005, the number of for-profit hospitals increased by 59\%, while the number of government-owned hospitals declined by $28 \%$, and the total number of hospitals declined by $11 \%$ (Anonymous 2007b). Consulting firm Arthur Andersen has predicted that by 2010 nearly a third of all hospitals will be for-profit, and the number of public hospitals would, between 2000 and 2010, decline by more than half (cited in Leonhardt, 2000: 106). In the four years leading up to 2005, the share of public hospitals spun off from the city administration and given a private legal form - most commonly, a GmbH, or limited liability company - increased from $28 \%$ to $44 \%$. Hospitals began doing more with less: between 1991 and 2005, the number of "cases" increased by $16 \%$, while staff numbers decreased by 3\% (Anonymous 2007b).

Attempts by Hamburg's politicians and managers to restructure the workplace have also been in line with industry trends. The outsourcing of services via subsidiary arrangements has become a common way for management to reduce headcounts, find partners with investment capital and expertise, and get tax advantages (Nagel, Haslinger and Meurer, 2002: pp. 120-154). Furthermore, employers have become increasingly willing to question collective bargaining. The chair of the German hospital association argued in a series of articles that changes in the political economy are forcing change in management practices. Without loosening job security rules, extending working times, introducing more low-wage work and introducing other forms of flexibility, he argues, more hospitals will leave the employers association (e.g. Rocke 2003).

The drive for cost cutting has intensified as a reimbursement scheme introduced in 2002, known as Diagnostic Related Groups (DRGs), has taken effect. Under DRGs, insurers - the most important of which are semi-public funds governed by labor and management representatives - pay a standard rate for a given condition, independent of the amount of time in the hospital or the hospital's costs. This helps insurers reduce expenditures by making hospital 
processes more transparent and comparable and by rewarding efficient hospitals, but will also drive inefficient hospitals into insolvency (Schütte 2004; Völpel-Haus 2003).

These reforms have taken place as public sector industrial relations have become increasingly disorganized. Though the formal structure of bargaining remains in place, employee and employer camps have fragmented, public enterprises have begun to exit from the employers association, and privatization and outsourcing have become pervasive. In 2003, the city-state of Berlin, whose left-wing coalition government, facing severe debt, negotiated an agreement with ver.di to leave the national framework and reduce pay and working time by $10 \%$. Shortly thereafter, the association of state governments left national bargaining. Bolstered by lower union density, the states demanded a greater increase in working time than that sought by municipal and federal governments (Bispinck 2006).

At the same time, the employees' side has been fragmenting. In earlier strikes, such as the one in 1992, the union could strike the public infrastructure of mass transit, harbors, and garbage collection. By 2006, many of these enterprises were privatized, covered by separate public-sector agreements or susceptible to strike breakers (ibid). ${ }^{\text {ii }}$ Furthermore, the Marburger Bund walked out of national bargaining in September 2005, and struck against the Land-owned clinics, with a demand for a $30 \%$ pay increase. Ver.di refused to support the physicians, preferring instead wage moderation and compression. In response, the physicians announced the creation of a new health care union to end ver.di's “dictatorship” (Die Welt, 8 August 2006).

In early 2006, in the wake of this fragmentation and the 2005 renegotiation of the overall public sector bargaining framework, a 14-week strike took place, the longest national public sector strike in German history. Ver.di made minor concessions over working time in order to bring the states back into bargaining and retain national bargaining. However, the new 
framework is a crazy quilt of rules, depending on the state and on sector-specific sideagreements known as Spartentarifverträge (Bispinck 2006).

In this context, social partnership in Hamburg proved brittle.

\section{Post-2001: Local political change}

As LBK was being restructured, local politics were also in upheaval. Deindustrialization became a major problem from the 1970s on, with nearly half of Hamburg's 292,000 manufacturing jobs lost between 1970 and 2003 (Statistisches Landesamt Hamburg n.d.). In response, the social democratic camp reoriented policymaking around the need to make Hamburg more attractive to business. They moved to attract private investment, mainly in the media, logistics and aerospace sectors. Compared to the old economy, however, the workplaces were not strongly unionized and their workers less loyal to the SPD. Some SPD votes went to the rival force on the left that emerged in the 1980s, the Greens, but a significant part of the old SPD milieu moved to the right.

In 2001, the SPD was voted out of the Senate and replaced by a coalition government of Conservatives (CDU), Liberal Democrats (FDP) and right wing populists (Schill). The Schill party was a short-lived political formation, led by a judge, known in the tabloid press as "Judge Merciless," for his law-and-order rhetoric. He received the most support from the three districts that, before the 1980s, had been strongholds of the SPD: Mitte, Bergedorf and Harburg (Anonymous 2007c). Harburg, where Schill's support was the strongest, contained the old cores of Hamburg's harbor-oriented industry and old working-class towns hit by deindustrialization.

By the 2001 election, local policymakers across the political spectrum were dissatisfied with the progress of LBK in adapting to cost pressures. Although the earlier round of 
restructuring had brought savings, two other costs had not been addressed: the payments due to retirees from the in-house pension scheme and investments in facilities. The Senate would not raise taxes to provide the hundreds of millions of euros needed to keep in step with technological change and the decay of the buildings, and all parties agreed that a private investor was necessary. Such investment was needed for the hospital's survival, it was argued, since, in the future LBK would be competing for patients against increasingly large and efficient private hospital chains. The Senate would have difficulty, however, getting a satisfactory price for the hospitals because public hospitals are not profitable enough to be considered hot commodities by financial institutions. Lohmann was a leading advocate of reform: with a competitive, marketoriented health care system, he argued, Hamburg could become a "health care metropolis" with synergies between hospitals and other health care-related businesses (e.g. $f \& w$ 1/2004: pp. 1315); without reform, the public would eventually face health care rationing (Schütte 2004).

In 2001, the newly elected Senate announced plans to sell a $74.9 \%$ stake in LBK to a private company, leading to a long battle with ver.di, the DGB and the works council. As an idea, privatization was nothing new - the SPD had also proposed market-based solutions, such as issuing LBK stock - but conservatives were willing to privatize without consulting trade unionists. Ver.di and works council officials made a counter-proposal, supported by the SPD, of finding a partner to buy a $49 \%$ share. This would have, they argued, raised funds while maintaining a government role as guarantor of LBK's mission. The conservatives countered that no investor would accept such terms. Since investors would be assuming risks, they argued, the purchaser would require control and therefore majority ownership ( $f \& w 1 / 2004)$. In late 2003, the Senate reached an agreement with the for-profit chain, Asklepios, to transfer the hospitals.

Trade unionists feared that, like many other hospitals that had been privatized, the new owners of LBK would abandon sectoral bargaining and strong codetermination; national ver.di 
Page 14

officials viewed Asklepios as especially anti-union. Furthermore, trade unionists feared that giving a for-profit hospital control of half of the region's hospital beds would lead to bankruptcies and hospital closures, as Asklepios boosted its bottom line by attracting the most lucrative customers. Along with the opposition political parties, they also objected to the low price that Asklepios was paying for the shares (there was doubt that Asklepios had actually made the best offer), the risk that the government was assuming (€75 million of the purchase price was contingent on revenue targets), and Asklepios' lack of experience running large hospitals (ver.di press release 15 December 2003; Abendblatt 28 November 2003).

In principle, worker representatives did want to obstruct change. The same works councilors had worked for years in "trusting cooperation" to reduce costs and agreed in principal to allowing private financing. However, the Senate's health care and public finance experts had little time for their alternative ideas and their offers to negotiate. On the one-year anniversary of ver.di's formation, its new local leader, Wolfgang Rose, announced its new anti-privatization campaign, cementing, as central to its identity, its resistance to policies of the CDU-led Senate.

With an organizational density of around $10 \%$ at LBK and a legal prohibition of political strikes, the union was in no position to take industrial action. However, trade unionists suspected that public opinion was against privatization, and that a public campaign would have a positive resonance in the news media. Despite cash flow problems due to overall membership decline, the union spent $€ 360,000$ on the campaign. Rose viewed campaigning as a way to get around workplace-level union weakness, strengthen ver.di's public credibility, and increase membership and involvement (Boehlke 2005).

In response to the Senate's new policy, Pumm, Rose and the works council rallied LBK workers, other union activists and officials, and a range of allies to organize one of the citystate's first ballot initiatives. ${ }^{\text {iv }}$ The slogan of this campaign was Gesundheit ist keine Ware! 
Page 15

["health is not a commodity!"]. The anti-privatization initiative was carried out by a coalition, including other unions (led by the local DGB), political parties, globalization critics attac, Marburger Bund, individual patients, ver.di's national office and others. Anti-privatization campaigners collected more than 100,000 signatures in the city's public squares and shopping areas and organized numerous rallies and demonstrations. Works councilors reported a massive growth in attendance at workplace meetings $(12,000$ of the signatures were collected in the workplace itself), and, over the opposition of management, they announced an unprecedented citywide meeting of LBK workers culminating in a rally with an estimated one thousand supporters. CDU politicians fought back with anti-communist language, equating state-owned hospitals with the combines of pre-unification East Germany (Abendblatt 8 May 2003).

\section{The vote and afterwards}

In late 2003, the Schill party collapsed, and a Bürgerschaft election was called. This crisis in the government took place as the bill to privatize LBK was passing through the council. For campaigners, this created a window of opportunity, because it meant that the approval for the privatization bill would be postponed, and the election for local government would be on the same date as the ballot initiative. In the January 2004 election, more than three-quarters of voters voted for the unions' initiative to stop privatization. Although this was a victory for ver.di, conservatives also achieved record success. While the SPD vote declined from $26.5 \%$ to $20.5 \%$, the CDU's share grew from $26.2 \%$ and $47.2 \%$. Many of their gains came from the former SPD strongholds that had voted for Schill; in Harburg, the CDU's share of the vote nearly doubled over 2001 (Anonymous 2007c). For the first time in Hamburg's post-war history, the conservatives had enough seats on the Bürgerschaft to form a Senate without a coalition partner. 
Page 16

With an unprecedented electoral success of its own, Senators ignored the antiprivatization vote. The city-state's highest court supported the Senate with a ruling that, although ballot initiatives were politically binding, they were not legally enforceable (Die Welt 16 December 2004). The Senate then proposed and passed a law to prevent balloting from happening at the same time as a state or federal election, shift signature-gathering into government offices, and raise the hurdle to approving an initiative at the ballot box, effectively abolishing the ballot initiative; in summer 2004 they raised the stakes further by discussing the sale of the remaining government stake in LBK.

The unions responded with a second campaign, Rettet den Volksentscheid! ("save the ballot initiative"). The leadership consisted of a retired IG Metall official, the head of an old bourgeois community organization (the Patriotic Society of 1765), and the head of a nonpartisan group devoted to promoting direct democracy, Mehr Demokratie. They received pro bono legal advice from a former judge on the federal constitutional court. The campaigners proposed a pair of initiatives to make ballot initiatives easier to conduct and legally binding, as well as a lawsuit challenging the constitutionality government's new law. Their lawsuit was partly successful, and the unions and their partners have, after another successful petition for a ballot initiative despite the new hurdles - good chances of restoring some mechanisms of direct democracy.

Meanwhile, Asklepios confirmed workers' fears, with demands for layoffs, longer hours and lower pay, and the creation of a new local employers association. In 2005, Asklepios managers, together with other smaller hospitals in the region, created a local employers association for hospitals to negotiate a separate agreement. Despite some earlier assurances that they would peg working conditions to public sector collective agreements, management unilaterally increased weekly working time for new employees from 38.5 to 42 hours, while 
demanding reductions in paid vacations, the introduction of more temporary workers, and the elimination of 1000 jobs, mainly through another round of restructuring in indirect services.

In October 2006, after ten months of warning strikes and hard bargaining, an agreement was reached. Although it binds the employer to the pay increases and working times of the TVöD, the agreement left out a pair of one-time payments and delayed a raise in performancerelated bonuses. It also lacked the ban on mandatory redundancies found in all earlier agreements and is subject to renegotiation separate from TVöD bargaining.

Ver.di reports that, over the course of the campaign for a collective agreement, union membership at LBK doubled, along with increases in the activity of works councilors and trade union activists in the workplace, and trench warfare continues in the workplace and polity. Asklepios and the Senate face ongoing headaches over nearly 2000 former LBK workers who are now exercising their right to return from the 1995 statute, creating further difficulties for the Senate (Die Welt 4 July 2007). Five years after ver.di began campaigning, even the conservative Hamburger Abendblatt has begun referring to "the eternal LBK controversy" (21 June 2007).

Why did social movement unionism replace co-management as the union strategy in Hamburg's hospitals? For LBK's workers and their representatives, the problem was not that a neo-liberal government had replaced a traditional one: social democrats and conservatives both advocated market-oriented reforms of health care and the public sector, and ver.di felt it could live with much of this agenda. The conservative Senate and the new employer Asklepios had a new strategy for making hospitals adapt to intensified competition. Using the language of strategic choice theory (Walton, Cutcher-Gershenfeld and McKersie, 1994), social democrats preferred to foster change, while conservatives preferred to force it. In pursuing privatization, the Senate pushed worker representatives out of their social partnership role and into one of organizing resistance. Rather than working together in joint programs to experiment and re- 
Page 18

make worker participation like the SPD Senate, the conservatives have shifted public sector industrial relations into a battlefield logic (see Behrens and Jacoby, 2004). As a result, the organs of co-determination changed their purpose to one of intensive deal-making between the state, the employer and the union, to one of information provision for a works council and local union under fire. The union shifted from an "insider" position with good access to elite decision making to an "outsider" position, excluded from government and management decisions (see Turner and Cornfield 2007: introduction). Table one sketches the change in Hamburg.

\section{Hospital restructuring and union responses beyond Hamburg}

The previous section described how the strategy of a large union in a single city changed in response to neo-liberal reforms threatening its public-sector membership. This section will discuss four other cities and two features of the regions that shape variations in union responses. One variable, union inclusion versus exclusion, was important in Hamburg: when local elites began to exclude unions from decision-making, social movement unionism became more of an option for organized labor. A second variable, economic crisis versus stability, was relatively unimportant in this change, mainly because Hamburg's economy has been relatively stable. In East Germany, unemployment has been much higher and fiscal pressures on government more intense; these economic pressures also made mobilization difficult. A comparison of municipal clinic restructuring in four large cities (Stuttgart, Cologne, Chemnitz, and Berlin) suggests that social movement unionism requires, not only the loss of old channels of influence, but also some amount of economic stability (table two).

Corresponding to the pre- and post-2001 situations in Hamburg are Cologne and Stuttgart, respectively. Stuttgart has a very strong manufacturing-based economy due to the boom of the auto industry since the late-1990s. While trade unions have a tradition of militancy, especially in metalworking, anti-union parties - the CDU, liberals, and the far right - dominate 
Page 19

regional politics. Against this background, ver.di has campaigned intensely around hospital restructuring with a solidly social movement approach. Using demonstrations and work with the church and other organizations in civil society, trade unionists began to contest layoffs and speedups in the kitchen, and, later, the centralization of all hospital functions on a single site. The result was initially a pledge by the city council to consider the unions' suggestions and, after other demonstrations, the union has become increasingly involved in detailed negotiations around the details of restructuring. Co-management in the sense of pre-2001 LBK, however, seems unlikely, after the bitter struggle between ver.di and the city during the 2006 strike.

In Cologne, a relatively stable service-based economy, campaigning has been less intense, because the union has had more opportunities for influence, and the campaigning that has taken place has fed into a pattern of strong co-management. In 2001, the SPD was voted out of office due to a corruption scandal, and was replaced by a conservative-liberal coalition. For a brief period in 2002, ver.di used public demonstrations to make its case to the public concerning the creation of a semi-autonomous city-owned hospital corporation. Due to a change in the government's junior partner (the liberals were replaced by the greens as the CDU's junior partner) and the choice of a conservative trade unionist as administrative director, the union called off the campaign and was able to make an agreement strengthening co-determination in the new organization.

The eastern city of Chemnitz is a stark contrast. Here, worker representation in municipal hospitals has fallen back into a social work function. During the 1990s, unemployment rose dramatically in the wake of a general collapse of East German industry; after 1997 the unemployment rate fluctuated between 17\% and 20\% (compared to the low teens in Hamburg and Cologne and 6\%-10\% in Stuttgart) (Anonymous 2007a). With the creation of a separate hospital corporation, outsourcing, pressure on workers to sign individual contracts that 
pay less than the collective agreement, and, in 2005, exit from the employers association, works councilors have advised and supported the workforce, but - despite their co-determination rights and presence on the city council - have felt powerless to influence change. Trade unionists attribute this powerlessness to the high level of unemployment, anti-union attitudes in the workforce and the minority position of workers on the supervisory board of the clinics. The governance structures of Chemnitz's hospital and the city government concentrate power in the hands of the mayor (an SPD member) and administrative director of the hospital; even trade unionists on the city council feel excluded from decision making. Nationally, ver.di officials confirm that it is more difficult to mobilize members in the east than in the west, and according to an evaluation of the national 2002-2003 campaign around health care reform, the vast majority of grass-roots activity was in the west (ver.di, 2003).

Economic crisis, however, does not prevent worker representatives from being involved in restructuring, as the case of Berlin shows. Initially, Berlin might seem like fertile ground for campaigning: it has a strong civil society with roots in the church and the student revolts of the late 1960s and, among Germany's Länder, has the most left-wing political culture. However, Berlin's economy collapsed after reunification, partly due to the loss of subsidies to West Berlin's industry, and partly due to the economic collapse of East Germany. While unemployment levels are similar to those of Chemnitz, public finances have been hit by the insolvency of a large Land-owned bank and the refusal by the federal government to provide a bailout. While the left coalition Senate (Social Democrats and Democratic Socialists) has not demanded the privatization of hospitals, it has pushed through layoffs, concessions and the creation of a semi-autonomous hospital corporation. Within a framework of strong codetermination - including the top personnel manager chosen by worker representatives - the government won dramatic reductions of staff and outsourcing to contractors not bound by the 
TVöD. In Berlin, strong union channels of influence, combined with severe public debt and unemployment, inclined ver.di more toward negotiating the details of retrenchment than of mobilizing its members and civil society. Perhaps the most dramatic example was the concessionary agreement of 2004, which reduced pay and working time for most of the city's workforce. Although they believe it was necessary, local ver.di officials estimate the resulting membership loss in the thousands.

The between-region comparison shows that exclusion from decision-making is not the only factor that matters for explaining social movement unionism. If it were, we would expect more mobilization in the city of Chemnitz; instead, worker representatives there are quiescent due to the economic pressures on their members created by high unemployment. Cologne and Berlin are both cases of co-management, with strong channels of influence and little mobilization; although in Berlin this it is a weak form due to high unemployment and fiscal pressures on the government. Stuttgart is, like post-2001 Hamburg, a case of social movement unionism. Lacking in strong channels of influence, ver.di in Stuttgart has been mobilizing members and community allies. This comparison confirms the importance of channels of influence in local government seen in the Hamburg case, but adds a second important factor that varies between regions, namely the extent of local economic crisis.

\section{Explaining change and variation in Germany}

The rise of campaigning is connected to a broader transformation of public sector industrial relations and the German political economy. Employers in the public and private sectors are seeking increased flexibility and reduced costs, sometimes by abandoning preexisting patterns of cooperation and negotiation with unions. Some politicians and government agencies are also shedding their old ties to unions. Because of this breakdown of neo- 
corporatism, "insider unionism” (Turner and Cornfield, 2006: introduction) is becoming increasingly ineffective or impossible, leading some unions to take on the characteristics of social movements. Hamburg is a case where ver.di has done so in response to privatization.

The dominant strand of comparative industrial relations makes an institutional argument that social movement unionism is unlikely in Germany (Baccaro 2003; Frege and Kelly 2004). Why do the cases above tell a different story? Germany is losing these special characteristics, partly due to the decline of unions (in terms of membership, political power and bargaining power) and partly due to political and economic pressures. In public hospitals, there is a consensus across the political parties that quality service can only be sustained through more involvement by the private sector. This can take the form of joint ventures, the spinning off of hospitals into separate public corporations or privatization. Whatever the choice, unions face demands to deviate from collectively bargained norms and therefore have to choose between quiescence, co-management, or social movement unionism.

Because of decisions made by politicians and administrators, in German hospitals, neocorporatist action does not necessarily follow from neo-corporatist structure. While Lucio Baccaro finds process of social partnership in countries without corporatist institutional structures (2003, p. 683), in Germany we currently see the reverse: while the quasi-corporatist institutional structure remains formally intact, the process of social partnership is breaking down. As employers have broken with old patterns of cooperation, ver.di has sought alternative forms of leverage. The breaking ranks of employers that led to the 2005 strike, the defection of Berlin's government and Hamburg's hospitals from the public sector framework and derecognition of collective bargaining by hospitals elsewhere all play a role. Ver.di corresponds less and less to the image of an institutionally embedded German trade union, with a public status secured by institutions, and more like a pluralist actor, changing its goals and pursuing 
them through mobilization or through co-management, in an experimental way. Although the case of Hamburg's hospitals confirms that the state matters in industrial relations (Godard, 2002), the public policies and employer strategies in Hamburg are similar to those seen in "liberal market economies."

As these arrangements break down and mobilizations outside of this system become more visible and important, it is worth asking why this change and within-country differentiation is taking place. One reason for the disorganization of Germany, suggested by the change over time in Hamburg and confirmed by the comparison between cities, is a push from political parties and employers for reforms of industrial relations. The actions of Asklepios and Hamburg's conservative Senate show that co-determination and sectoral bargaining do not prevent employer unilateralism. Elites made a choice to exclude worker representatives under the assumption that trade unionists would reject the necessary measures. It is not only that they interpreted the need for change in neo-liberal terms: they could have followed the Social Democrats' example in reorienting public service provision around the market with the support of trade unions.

A second reason for within-country variation in union strategies, suggested in the between-city comparison, is the uneven distribution of economic growth in Germany. It is well known that private German companies in crisis tend to engage in collective bargaining, often by making a business case mixed with threats (Massa-Wirth and Seifert 2004). A literature also exists on how the economic crisis in the East has affected industrial relations, leading to the establishment of the dual system there, but in a weaker form, highly susceptible, once again, to concession bargaining, or even the derecognition of bargaining, partly because of the pressure that the threat of unemployment puts on workers (Artus 2001). Furthermore, in public sector industrial relations, the literature on change has shown that fiscal pressure on states, especially due to debt, is forcing states to change their policies (Schulten and Dribbusch 2004). All of this 
applies to the hospital cases: in Berlin and Chemnitz, ver.di had immense difficulty in mobilizing people due to unemployment, and the weakness of economic growth since reunification limited the resources to pay for public services. While intergovernmental transfers continue to take place from rich states to poor ones (the so-called Länderfinanzausgleich), they have been insufficient to bridge the inequalities between east and west or to rescue Berlin's state government from its bank crisis.

This shift to social movement unionism in some German hospitals may not mean that institutions do not matter, but if social partnership is breaking down, without major changes in industrial relations rules, institutions probably matter less. What matters for actors involved in the restructuring of municipal hospitals is outside the system of industrial relations. Rather than appealing to the common framework of goals and procedures institutionalized by an industrial relation system, ver.di in Hamburg has begun to work on a less certain terrain, in a more contentious manner. They rely not so much on regularized channels of influence or well-tested sources of power, but rather on an experimental search for new levers. This experimentation involves finding issues that appeal to the broader public, especially in health care and the public sector. In the battle in Hamburg against privatization, ver.di and the works council appealed to two main goals beyond job retention and worker well-being: local democracy and the state's role in providing for basic human needs. This experimentation, however, can also involve mobilizing or finding insider channels of influence, as in Berlin and Cologne. Sometimes, like in Chemnitz and Berlin, high unemployment makes it difficult to mobilize the workforce; in Hamburg, Cologne and Stuttgart, the union has had more ability to mobilize people. In Cologne, Berlin and (pre-2001) Hamburg, the union had channels of influence that led to demobilization, as trade unionists took on a role in cutting the workforce and speeding up work. Union ability and willingness to organize resistance thus depends not just on the country, but also on region- 
specific factors, such as local economic conditions and political constellations in local government.

\section{Conclusion: the disembedding of German trade unions}

The purpose of this paper has been to contest the image of German unions as constrained by a formerly favorable institutional framework. In the case of Hamburg's hospitals, a campaign has taken place that corresponds to definitions of social movement unionism derived from the U.S. experience. While the union failed to stop privatization, it succeeded in repeatedly embarrassing the Senate and the employer in public, setting up new relations of cooperation with local civil society, preventing the employer from breaking with the framework of public sector collective bargaining, and revitalizing its activist structures and membership in the workplace. This is hardly a case of shoring up traditional German social partnership through conflict. The campaign has been about blocking neo-liberal reforms, and there is little sign that contention could lead to more union influence over the details of restructuring in the workplace or its political-economic causes.

While social movement unionism depends on region-specific factors, it needs to be emphasized that the national level also matters. Hospital restructuring emanates from the nation state and national political parties, via the statutory insurance funds. While social movement unionism can address the workplace-level effects by mobilizing against the local elites who make decisions about health care provision, local campaigners have no way to address the national political changes behind the changes. Their attempted "mixed form" campaign to link local struggles over restructuring with national attempts to influence health care reform was a failure (ver.di 2003). 
This analysis is not universally generalizable, even if it does fit a wide range of evidence from large municipal hospitals. It matters that the struggle is over a public good, health care, and took place (initially) in the public sector. In Hamburg, the goods at stake in the hospitals are fundamentally different from those at the city's other large employer, Airbus. This is not to say that German industrial relations institutions are sufficient for worker representation in a large metalworking firm: mobilization and political action have been important there, as well. But Airbus workers have rallied around much more "economistic" demands, mainly job security, and have had to overlook the costs to the environment and the public purse. While ver.di has built a broad coalition (including both attac and the Patriotic Society of 1765), the coalition for Airbus expansion has mainly involved elites, often in conflict with other parts of civil society, such as environmentalists and property owners (Greer 2007).

Without proposing a German "model" or "variety" of social movement unionism, at least three U.S.-German differences emerge from the stories. One has to do with LBK being within the public sector. While government employees in the US organized around broad social goals that, they argued, the government should pursue, this came at a time of expansion, rather than retrenchment. Johnston (1994) shows that social movement unionism in California's public sector quieted down in the 1980s, as the government came under fire from the tax revolt and politics as a whole lurched to the right. In Hamburg, by contrast, ver.di has begun using social movement tactics to fight retrenchment.

A second difference has to do with the process of union strategizing. Voss and Sherman (2000) argue that unions adopt new organizing policies when new leaders emerge with experience outside trade unionism and where national unions step in to implement organizing policies. Like the organizing unions in that study, ver.di in Hamburg is in crisis and looking for alternatives. But far from waiting for the national union to step in, the initiative came from the 
local level, and from activists and staff with little experience in other social movements. Ver.di has had few layoffs and no overall vision of organizing to implement in its local units.

A third difference has to do with the lack of mandatory union membership in Germany, which creates a special tension between labor-management cooperation and union vitality. US industrial relations rules allow mandatory union membership, while in Germany union membership is always officially voluntary. Unlike their American counterparts, local German unions that participate in painful, unpopular reforms tend to lose members, activists, and (potentially) even control of works councils. Conversely, in situations of struggle, union membership tends to increase, as it has in Hamburg's privatized hospitals.

This article has shown what scholars call social movement unionism does indeed exist in Germany and has sketched the conditions under which it emerges in municipal hospitals. It also raises other questions that will require future research. How does the big picture of trade union strategy in Germany really compare with that in the English-speaking world? Will German unions recover their vitality through social movement tactics, or are these measures too limited, too short-term, and too defensive? Does participation inevitably lead to demobilization, or are there conditions under which it can fit into a unions' strategy to mobilize workers? Asking questions like these would inject realism into the picture of "social Europe" among industrial relations scholars and shed light on the workings of union renewal and decline more generally. 
Table 1. Change over time in industrial relations in Hamburg's hospitals

\begin{tabular}{|c|c|c|}
\hline & 1995-2001 & Post-2001 \\
\hline Local politics & Stable SPD dominance & $\begin{array}{l}\text { Weaker SPD, unstable political party } \\
\text { system }\end{array}$ \\
\hline $\begin{array}{l}\text { Employer IR } \\
\text { strategy }\end{array}$ & Fostering & Forcing \\
\hline Logic of IR & $\begin{array}{l}\text { Experimentalism: joint reform } \\
\text { projects within the framework of } \\
\text { public sector bargaining }\end{array}$ & $\begin{array}{l}\text { Battlefield: struggle over a new } \\
\text { framework of collective bargaining and } \\
\text { in-house worker representation }\end{array}$ \\
\hline Union status & Insider & Outsider \\
\hline Union strategy & $\begin{array}{l}\text { Co-management within the } \\
\text { bounds of workplace co- } \\
\text { determination }\end{array}$ & $\begin{array}{l}\text { Social movement unionism and coalition } \\
\text { building beyond the workplace }\end{array}$ \\
\hline $\begin{array}{l}\text { Dominant union } \\
\text { goals }\end{array}$ & $\begin{array}{l}\text { Keeping the hospitals } \\
\text { competitive }\end{array}$ & $\begin{array}{l}\text { Public service provision, local } \\
\text { democracy, and retention of collective } \\
\text { bargaining }\end{array}$ \\
\hline Union vitality & Membership loss, demobilization & Membership gain, mobilization \\
\hline
\end{tabular}


Table 2. Differences between hospital industrial relations in different cities

\begin{tabular}{ccc}
\hline & Union inclusion & Union exclusion \\
\hline Economic crisis & Weak co-management (Berlin) & Quiescence (Chemnitz) \\
\hline Economic stability & $\begin{array}{c}\text { Strong co-management } \\
(\text { Cologne, Hamburg post- } \\
\text { 2001) }\end{array}$ & $\begin{array}{c}\text { Social movement unionism } \\
\text { (Stuttgart, Hamburg post- } \\
\text { 2001) }\end{array}$ \\
\hline
\end{tabular}




\section{References}

Anonymous. 2007a. Arbeitslose und Arbeitslosenquote (abh. EP) sowie ausgewählte Strukturen (Frauen, Ausländer, unter 25 Jahre, Langzeitarbeitslose, Schwerbehinderte) nach Kreisen ab Dezember 1984. Nuremberg: Bundesagentur für Arbeit.

Anonymous. 2007b. Grunddaten Der Krankenhäuser 2005. Bonn: Statistisches Bundesamt.

Anonymous. 2007c. Wahldatenbank Seit 1965. http://www.statistik-nord.de/fileadmin/wahldb/

Artus, Ingrid. 2001. Krise des deutschen Tarifsystems: Die Erosion des Flächentarifvertrags in Ost und West. Wiesbaden: Westdeutscher Verlag.

Baccaro, Lucio . 2003. "What is Alive and What is Dead in the Theory of Corporatism." British Journal of Industrial Relations 41 (December): 683-706.

Baccaro, Lucio, Kerstin Hamann, and Lowell Turner. 2003. "The Politics of Labour Movement Revitalization: The Need for a Revitalized Perspective." European Journal of Industrial Relations 9 (March): 119-133.

Behrens, Martin and Wade Jacoby. 2004. "The Rise of Experimentalism in German Collective Bargaining” British Journal of Industrial Relations 42 (March): 95-123.

Bispinck, Reinhard. 2006. "Mehr als ein Streik um 18 Minuten - Die Tarifauseinandersetzungen im öffentlichen Dienst 2006." WSI Mitteilungen 59 (July): 374-381.

Boehlke, Nils. 2005. Direktdemokratische Verfahren als strategisches Instrument der Gewerkschaften zur Verhinderung von Privatisierung. Masters' Thesis, University of Hamburg, Department of Political Science.

Brueckner-Bozetti, Peter, and Simone Schweizer. 2000. Krankenhausmanagement und Arbeitnehmerstrategie: Ein Projekt Der Gewerkschaft ÖTV und des Gesamtpersonalrates des LBK Hamburg zur Unternehmens- und Beschäftigungssicherung. Frankfurt am Main: Mabuse Verlag.

Doellgast, Virginia, and Ian Greer. 2007. "Vertical Disintegration and the Disorganization of German Industrial Relations." British Journal of Industrial Relations 45 (March):55-76.

Ebbinghaus, Bernhard. 2005. "Hoffnung allein ist nicht genug." Die Mitbestimmung 51 (January):22-25.

Frege, Carola, Edmund Heery, and Lowell Turner. 2004."Coalition Building in Comparative Perspective." In Varieties of Unionism: Strategies for Labor Movement Renewal in the Global North, edited by Carola Frege and John Kelly, pp. 137-158. New York: Oxford University Press.

Frege, Carola, and John Kelly. 2004. Varieties of Unionism: Strategies for Labor Movement Renewal in the Global North. Oxford: University Press. 
Godard, John. 2002. "Institutional Environments, Employer Practices, and States in Liberal Market Economies." Industrial Relations 41 (April): 249-286.

Greer, Ian. 2007."Special Interests and Public Goods: Organized Labor's Coalition Politics in Seattle and Hamburg." In Labor in the New Urban Battlegrounds: Local Solidarity in a Global Economy, edited by Lowell Turner and Daniel Cornfield, pp. 193-210. Ithaca: ILR Press.

Hassel, Anke. 1999. Gewerkschaften und Sozialer Wandel: Mitgliederrekrutierung und Arbeitsbeziehungen in Deutschland und Grossbritannien. Baden-Baden: Nomos.

Johnston, Paul. 1994. Success while Others Fail: Social Movement Unionism and the Public Workplace. Ithaca, NY: ILR Press.

Leonhardt, Marion. 2000. "Beschäftigte in Gesundheitswesen zwischen Arbeitshetze und Eigenverantwortung." In Therapien fuer ein krankes Gesundheitswesen, edited by Helmut Paetow, Manfred Fiedler, and Marion Leonhardt, pp. 99-117. Hamburg: VSA.

Lopez, Steven Henry. 2004. Reorganizing the Rust Belt: an Inside Study of the American Labor Movement. Berkeley: University of California Press.

Massa-Wirth, Heiko, and Hartmut Seifert. 2005. "Pacts for Employment and Competitiveness in Germany." Industrial Relations Journal 36 (May): 217-240.

Moody, Kim. 1997. Workers in a Lean World. London: Verso.

Nagel, Bernhard, Sebastian Haslinger, and Petra Meurer. 2002. Mitbestimmungsvereinbarungen in öffentlichen Unternehmen mit privater Rechtsform. Baden-Baden: Nomos.

Rehder, Britta. 2003. Betriebliche Bündnisse fuer Arbeit in Deutschland: Mitbestimmung und Flächentarif im Wandel. Frankfurt am Main: Campus.

Rehder, Britta. 2006. "Legitimitätsdefizite des Co-Managements. Betriebliche Bündnisse als Konfliktfeld zwischen Arbeitnehmern und betrieblicher Interessenvertretung." Zeitschrift fuer Soziologie 25 (June): 227-242.

Riexinger, Bernd, Christel Meyer zu Berstenhorst, and Iwo Garbe. 2007. Unser Streik 2006. Stuttgart: ver.di Bezirk Stuttgart.

Rocke, Burghard. 2003. "Flucht aus dem BAT und aus der Zusatzversorgung." Das Krankenhaus 95 (June): 449-453.

Schulten, Thorsten, and Heiner Dribbusch. 2004. Trends and Developments in German Public Sector Collective BargainingPaper presented at the 2004 IREC conference, Utrecht, 26-28 August.

Schütte, Gisela. 2004. Heinz Lohmann. Mut Zum Wandel: Texte Zur Entwicklung Der Gesundheitswirtschaft. Melsungen: Bibliomed.

Statistisches Landesamt Hamburg. 500 Jahreszeitreihen (Seit 1970): Erwerbstätigkeit. 
Streeck, Wolfgang. 2001. "High Equality, Low Activity." Industrial and Labor Relations Review 54 (April): 698-706.

1992. Social Institutions and Economic Performance. London: Sage.

Thelen, Kathleen, and Ikuo Kume. 2006. "Coordination as a Political Problem in Coordinated Market Economies." Governance 19 (January): 11-42.

Thelen, Kathleen. 1991. Union of Parts: Labor Politics in Postwar Germany. Ithaca: Cornell University Press.

Turner, Lowell and Daniel Cornfield. Forthcoming. Labor in the New Urban Battlegrounds: Local Solidarity in a Global Economy. Ithaca: ILR Press.

Turner, Lowell. 1991. Democracy at Work. Ithaca: Cornell University Press.

ver.di. 2003. Aus:wertung Gesundheitskampgne - Erkentnisse und Erfahrungen zur Kampagnenarbeit in ver.di. Berlin: ver.di.

Völpel-Haus, Dirk . 2003. Auswirkungen und Gefahren bei der Einführung der DRG's aus der Sicht der Bundesfachgruppe Krankenhäuser der ver.di Bundesverwaltung. Berlin: ver.di.

Voss, Kim, and Rachel Sherman. 2000. "Breaking the Iron Law of Oligarchy: Union Revitalization in the American Labor Movement." American Journal of Sociology 106 (September): 303-349.

Walton, Richard, Joel Cutcher-Gershenfeld and Robert McKersie. 1994. Strategic Negotiations: A Theory of Change in Labor-Management Relations. Ithaca: ILR Press.

\footnotetext{
${ }^{\text {i } M a n a g e r s ~ a t ~ t h e ~ h o s p i t a l ' s ~ n e w ~ o w n e r, ~ A s k l e p i o s, ~ w e r e ~ n o t ~ a v a i l a b l e ~ f o r ~ c o m m e n t . ~}$

ii It is controversial to refer to German industrial relations as "neo-corporatist", since wages are set at sectoral, rather than national level, and the country has not had success with tripartite pacts. Nevertheless, the industrial relations system traditionally provided a functional equivalent, due to its ability to use networks of works councilors and firms, coordinated by unions and employers associations to coordinate change (Thelen 1991).

${ }^{\text {iii }}$ During the 2006 strike, Stuttgart's city government used private contractors - mostly firms with no works councils or collective bargaining - to pick up trash. This led to a blockade of an incinerator and an incident in which a driver rammed a group of strikers (Riexinger, Meyer zu Berstenhorst, Christel and Garbe 2007; ver.di Bezirk Stuttgart, 2006: 32-35, 49). Afterwards, the city moved to privatize garbage collection completely.

${ }^{\text {iv }}$ In a ballot initiative, voters are asked to vote yes or no on a piece of legislation or a recommendation to a legislature. In Hamburg, it happens in several stages, including a Volksinitiative, a small initial show of public interest, a Volksbegehren, a much larger petition, and a Volksentscheid, an actual ballot. Hamburg was one of several states that passed such legislation in the 1990s, as part of a larger set of post-unification constitutional reforms.
} 